\title{
Ecosystem services of Kampinos National Park for the city of Warsaw
}

\author{
Marta Deptuła \\ Kampinos National Park \\ Suwalska 38 m. 63, \\ 03-252 Warsaw, Poland \\ m.deptula@kampinoski-pn.gov.pl
}

\begin{abstract}
Kampinos National Park (KNP) is adjacentto Poland's capital city. It covers an area of 38544 ha characterized by high diversity of mainly forest ecosystems, which has a vital influence on the adjacent urbanized areas. The extent of this beneficial impact have not been fully analysed and understood. This paper aims to identify the ecosystem services provided by KNP to the Warsaw agglomeration and suggests methods of their quantification and economic evaluation. Wider application of ecosystem services concept could provide managers of KNP with a powerful tool which may help raise awareness of the actual value of KNP ecosystems and improve their protection.
\end{abstract}

Keywords: Kampinos National Park, ecosystem services, evaluation, urbanized areas.

\section{Introduction}

The importance of natural environment for human health and prosperity is an indisputable fact in the minds of nowadays people of science. The extent of our species' dependency on nature continues to be an object of interest of the entire spectrum of scientific disciplines, from physical to social. However, the general public's common understanding of the actual value of natural environment has never quite been able to keep up with expert knowledge, which in far too many cases has brought disastrous results. The development of the ecosystem services concept, which merges findings and methods from different disciplines and attempts to translate abstract values into more tangible ones, offers a chance to improve scientific knowledge about the worth of our ecosystems and their contribution to the welfare of societies (DEFRA, 2007). But what may be even more important, particularly from the point of view of nature conservation practitioners, is the fact that this new paradigm provides us with a tool to disseminate and promote environmental knowledge in a new, integrated and comprehensive way, which may significantly increase the efficacy of our actions and, therefore, the conservation efforts as a whole. It is crucial that the general public and the decision makers perceive ecosystems composing the natural environment as a form of capital asset- a vital resource, equal in worth to the society's physical, economic, human, social, and intellectual capital (UNEP, 2005). It is particularly important on areas where high natural values and those who work to protect them are a side in a conflict of interests. Kampinos National Park, subjected 
to increasing investment pressure, is an example of such area. Ensuring better understanding of the actual value of KNP ecosystems for the neighbouring urbanized areas, particularly Warsaw, seems to be one of the park's major tasks for the following years. The following paper attempts to identify the most vital ecosystem services of Kampinos National Park for the city of Warsaw and provide an introductory suggestion of the methods which could be applied for their measurement and evaluation.

\section{Definition and classification of ecosystem services}

The concept of ecosystem services is one of the more recent approaches to the relationship between humans and nature. It combines findings from ecological and economic sciences, aiming at creating unified system of assessment and evaluation of the value of natural environment. Most general definition of ecosystem services states that they are products and functions of ecosystems from which people obtain benefits (Constanza et al, 2006, Solon, 2008, UNEP, 2005). The products include material goods which are used directly, meanwhile beneficial ecosystemic functions are centred around maintaining and improving conditions for life on Earth. They ensure the fulfilment of human needs, from most basic to the highest, both individual and those of entire societies. Environmental services paradigm allows to consider natural environment in terms of its assets, which in a measurable way contribute to the enhancement of economic development and investment processes, provide opportunities for employment and increase the quality of life (DEFRA, 2007). What is equally important, the concept of ecosystem services highlights the fact that improving or degrading the condition of environmental resources increases or reduces not only current, but also future benefits offered by the ecosystems. It offers a tool for assessment of the results of development and investments initiatives, conservation activities, spatial planning policies and, probably most importantly, for raising ecological awareness among the general public and the authorities of all levels (Brander, McEvoy, 2012, DEFRA,2007, NRC, 2005, Solon, 2008).

Most popular classification of ecosystem services divides them into four basic categories (UNEP, 2005). These are: provisioning services, regulating services, supporting services and cultural services. Provisioning services are most easily identified and analyzed even for separate ecosystems as they encompass material goods- various products obtained from natural environment, such as food or timber. Regulating ecosystem services are the benefits that humans derive from ecosystem processes and functions, for example air purification or flood prevention. Supporting ecosystem services include processes that maintain the functioning of ecosystems, allowing them to provide benefits for humans. This category is most challenging in assessment, since it includes processes which offer no direct profit to humans, such as soil formation or provision of habitat. The last category, cultural ecosystem services, encompasses intangible benefits obtained through recreation, intellectual development, artistic inspiration, spiritual enrichment etc. It can be observed that according to such classification ecosystem services include not only immediate profits offered to people by particular ecosystems, but also processes of different scale that sustain the ecosystemic capacity to provide those profits (de Groot et al, 2002). 


\section{Methods of valuation of ecosystem services}

The issue of valuation of ecosystem services has been recurring in numerous works for almost two decades (Solon, 2008). Methods available nowadays are divided into two basic categories, depending on the results: those that elicit economic values and those that elicit non-economic values (DEFRA, 2007). They display high diversity in terms of used tools, possible applications and other aspects (Tab.1). For the purpose of this paper the focus will be put on economic evaluation methods, since they provide conservation practitioners with a tangible argument in negotiations with various groups of interest.

Table 1. Economic evaluating methods of ecosystem services

\begin{tabular}{|c|c|}
\hline Method & Application \\
\hline Market prices & $\begin{array}{l}\text { - Assessment of value of traded products and services. } \\
\text { - Mainly applicable to provisioning services } \\
\text { - Does not capture non-use values. } \\
\text { - Measures direct and indirect use value. }\end{array}$ \\
\hline $\begin{array}{l}\text { Avoided damage/ } \\
\text { averting behaviour }\end{array}$ & $\begin{array}{l}\text { - Assessment on the basis of the price which individuals are willing to pay for } \\
\text { mitigation of negative environmental impacts } \\
\text { - Applicable to all ecosystem services } \\
\text { - Measures direct and indirect use value }\end{array}$ \\
\hline $\begin{array}{l}\text { Production function } \\
\text { approach }\end{array}$ & $\begin{array}{l}\text { - Assessment of given ecosystem service from the point of view of its influence on } \\
\text { production of a market good. } \\
\text { - Applicable to all ecosystem services. } \\
\text { - Measures indirect use value }\end{array}$ \\
\hline Hedonic pricing & $\begin{array}{l}\text { - Assessment of environmental components based on modelling the impact of all } \\
\text { possible factors influencing the price of the property } \\
\text { - Applicable to services related to air quality, aesthetic values and other aspects that } \\
\text { impact property prices } \\
\text { - Measures direct and indirect use value }\end{array}$ \\
\hline Travel cost method & $\begin{array}{l}\text { - Assessment based on an assumption that the costs of touristic travel to a given site } \\
\text { can be used as a proxy for the recreational value of that destination } \\
\text { - Applicable to services which influence the recreational value of the site } \\
\text { - Measures direct use value }\end{array}$ \\
\hline $\begin{array}{l}\text { Random utility } \\
\text { models }\end{array}$ & $\begin{array}{l}\text { - Assessment method based on the travel cost method, used to verify the effect of } \\
\text { changes in environmental characteristic of a given site } \\
\text { - Applicable to services which influence the recreational value of the site } \\
\text { - Measures direct use value }\end{array}$ \\
\hline Contingent valuation & $\begin{array}{l}\text { - Assessment based on a price that an individual is willing to pay for a particular } \\
\text { change in the environment or lack or thereof } \\
\text { - Applicable to all ecosystem services } \\
\text { - Measures direct and indirect use value }\end{array}$ \\
\hline
\end{tabular}




\begin{tabular}{|l|l|}
\hline Method & Application \\
\hline Choice modelling & $\begin{array}{l}\text { Assessment based on a price that an individual is willing to pay for a particular } \\
\text { combination of changes in the environment and the hierarchy in which the } \\
\text { respondents place a number of such combinations } \\
\text { - Applicable to all ecosystem services } \\
\text { - Measures direct and indirect use value }\end{array}$ \\
\hline Opportunity cost & $\begin{array}{l}\text { - Assessment based on the value of the benefits that an individual resigned from in } \\
\text { order to protect, enhance or create a particular environmental asset }\end{array}$ \\
\hline $\begin{array}{l}\text { Cost of alternatives/ } \\
\text { substitute goods }\end{array}$ & $\begin{array}{l}\text { Applicable to all ecosystem services } \\
\text { - Assessment considering the cost of providing a substitute good that has a similar } \\
\text { function to the environmental good }\end{array}$ \\
\hline $\begin{array}{l}\text { Replacement cost } \\
\text { method }\end{array}$ & $\begin{array}{l}\text { Application depending on existence of the substitute, theoretically possible for all } \\
\text { ecosystem services. }\end{array}$ \\
\hline $\begin{array}{l}\text { Measures direct and indirect use value } \\
\text { environmental asset to its original state, using this for evaluation of the benefit of } \\
\text { restoration } \\
\text { Applicable to all ecosystem services }\end{array}$ \\
\hline
\end{tabular}

\section{Kampinos National Park and Warsaw}

Kampinos National Park (KNP) represents a narrow group of national parks that are located in the immediate vicinity of a capital city of a country. It was established in 1959 to ensure protection of natural values of Kampinos Forest and its historical and cultural heritage. The park encompasses the best-preserved system of inland sand dunes in Europe. It takes form of several latitudinally oriented belts interspersed with wetlands. Such geological and geomorphologic structure results mainly from fluvioglacial and fluvial processes related to the old Vistula River, which nowadays flows in parallel to the park's northern borders, and subsequent eolic accumulation. As a result of such heterogeneous abiotic conditions, the Park is characterized by high diversity of lowland habitats; so far over 140 plant communities have been identified (Solon, 2003). 73\% of the park's territory is covered with different types of forests. Remaining areas include mostly meadows and pastures (15\%) and arable lands (5\%). In total, the park covers an area of $38544 \mathrm{ha}, 12 \%$ of which is encompassed by areas under strict nature protection, equalling this of a nature reserve. Remaining areas are mainly under active nature protection $(70,3 \%)$, but there is also $17,6 \%$ of privately owned lands which fall under landscape protection regime (Kampinoski Park Narodowy, 2011). The entire park is a part of Natura2000 Network with a double status of Special Protection Area (designated under the EU Directive on the Conservation of Wild Birds) and Special Area of Conservation (designated under the EU Habitats Directive). It is protected by extensive buffer zone, which covers 37756 ha of highly diversified areas; they range from secluded nature reserves to highly urbanized districts of Warsaw, two of which neighbour directly with the areas of active nature protection of the park. The importance of KNP for Warsaw - the capital of Poland, has been recognized by tourists, nature specialists and spatial planners as early as the first 
decades of the XX century (Król, Skolimowska-Król, 2004). It would seem that the value of close proximity of such large protected area, composed mainly of forest ecosystems, from the point of view of a capital agglomeration is unquestionable. However, on the outskirts of a rapidly growing city inhabited by over $1,7 \mathrm{mln}$ people intangible values associated with nature protection frequently stand second to the needs of development processes. It might stem from the fact that the exact extents of Kampinos National Park's beneficial influence on the surrounding urbanized areas have not been fully analyzed and understood. The evaluation of ecosystem services of KNP, in the meaning of those products and functions of the ecosystems, which are useful for the human society, has been limited to those whose final product can be directly translated to monetary value, e.g. forestry production. The extent and spatial distribution of majority of the KNP ecosystem services can be estimated on the basis of research and monitoring results from different fields. Partly due to this deficiency of knowledge ecosystems of KNP are subjected to the damaging impacts of increasing, multifaceted anthropopressure.

\section{Ecosystem services of Kampinos National Park}

There is no doubt among experts that the influence of Kampinos National Park ecosystems on Warsaw agglomeration is crucial from the point of view of proper functioning of the city (Król, Skolimowska-Król, 2004). However, as it was mentioned before, no precise analysis has been conducted in regards to the exact nature of this influence, its components, main groups of recipients and estimated economic value. According to Solon (2008), currently there are four main approaches to the issue of identifying and analysing ecosystem services:

1. Precise identification of ecosystem service in terms of the relation between specific human activity and particular resource supplied by nature, necessary for this activity;

2. Detailed analysis of structure and function of ecosystems accompanied by identification of groups of organisms directly supplying the goods used by society;

3. Identification of need for ecosystem services depending on different forms of land-use;

4. Delineation of heterogenic spatial units and their assessment on the basis of the degree of their anthropogenic transformation as an indirect measure of quality of ecosystem services.

This paper adapts a more general approach, outlining main ecosystem services and major ecosystems involved in their provision on the basis of expert knowledge concerning Kampinos National Park ecosystems and available data regarding their use by different groups of users. It is the only method available in light of lack of specific research concerning ecosystem services. However, even such introductory analysis can have its uses, mainly as a starting point for future research and an aid in public relations.

Ecosystem services of Kampinos National Park fall into all four categories: regulating, supporting, cultural and provisioning (Tab 2.). They have varying scales: some are restricted to local recipients, that is- communes located within the Park and its immediate neighborhood, including Warsaw, but some are characterized by regional, national or even global scale of influence. However, there are reasons to claim that the capital derives more profit from them than any other community. It is due to the fact that Warsaw profits most from two most significant categories of KNP ecosystem services- regulating and cultural. The following overview focuses on those two categories, since these services bring major benefits to local communities, including Warsaw, and more easily than supporting services are possible to quantify and valuate using economic methods (DEFRA,2007). The significance of provisioning services of KNP is marginal due to restrictive use of the area 
resulting from its protected status - those services are merely a by-product of activities related to active protection of the Park ecosystems, and their scale is quite limited.

Table 2. Main ecosystem services of Kampinos National Park for its surroundings and suggested economic valuation method

\begin{tabular}{|c|c|c|c|c|c|}
\hline Cat. & $\begin{array}{l}\text { Ecosystem } \\
\text { service of KNP }\end{array}$ & $\begin{array}{l}\text { Main KNP cosys- } \\
\text { tems providing } \\
\text { the service }\end{array}$ & Proposed indicator/unit & $\begin{array}{l}\text { Scale of } \\
\text { service }\end{array}$ & $\begin{array}{l}\text { Proposed economic } \\
\text { valuation methods }\end{array}$ \\
\hline \multirow{3}{*}{ 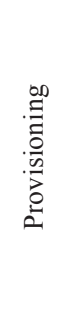 } & $\begin{array}{l}\text { Production } \\
\text { of energetic } \\
\text { biomass }\end{array}$ & Fresh meadows & $\begin{array}{l}\text { Amount of produced } \\
\text { biomass/cubic metres/year }\end{array}$ & Local & Market prices \\
\hline & $\begin{array}{l}\text { Production of } \\
\text { fodder }\end{array}$ & Fresh meadows & $\begin{array}{l}\text { Amount of produced } \\
\text { fodder/cubic metres/year }\end{array}$ & Local & Market prices \\
\hline & $\begin{array}{l}\text { Production of } \\
\text { timber }\end{array}$ & Pine forests & $\begin{array}{l}\text { Amount of produced } \\
\text { timber/cubic metres/year }\end{array}$ & Local & Market prices \\
\hline \multirow{4}{*}{ 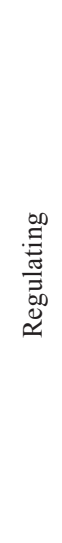 } & $\begin{array}{l}\text { Air quality } \\
\text { regulation }\end{array}$ & $\begin{array}{l}\text { Pine and alder } \\
\text { forest }\end{array}$ & $\begin{array}{l}\text { Pollutants absorption } \\
\text { capacity } / \mathrm{kg} / \mathrm{ha} / \text { year }\end{array}$ & $\begin{array}{l}\text { Local } \\
\text { Regional }\end{array}$ & $\begin{array}{l}\text { Avoided damage } \\
\text { Cost of alternative }\end{array}$ \\
\hline & $\begin{array}{l}\text { Climate } \\
\text { regulation }\end{array}$ & $\begin{array}{l}\text { Pine and alder } \\
\text { forest }\end{array}$ & $\begin{array}{l}\text { Carbon dioxide sequestra- } \\
\text { tion/ tonnes of } \mathrm{CO} 2 / \text { ha } \\
\text { Difference between average } \\
\text { summer temperatures in } \\
\text { the park and in the city of } \\
\text { Warsaw/Celsius degrees }\end{array}$ & $\begin{array}{l}\text { Local } \\
\text { Regional } \\
\text { National } \\
\text { Global }\end{array}$ & $\begin{array}{l}\text { Market prices of } \\
\text { carbon } \\
\text { Cost of alternative }\end{array}$ \\
\hline & $\begin{array}{l}\text { Water flow } \\
\text { regulation and } \\
\text { flood prevention }\end{array}$ & All ecosystems & $\begin{array}{l}\text { Water storage } \\
\text { capacity/ } \mathrm{mm} / \text { year }\end{array}$ & $\begin{array}{l}\text { Local } \\
\text { Regional }\end{array}$ & $\begin{array}{l}\text { Avoided damage } \\
\text { Cost of alternative }\end{array}$ \\
\hline & $\begin{array}{l}\text { Erosion } \\
\text { prevention }\end{array}$ & Pine forests & $\begin{array}{l}\text { Avoided soil yield/ } \\
\text { tonnes/ha/year }\end{array}$ & Local & $\begin{array}{l}\text { Avoided damage } \\
\text { Cost of alternative }\end{array}$ \\
\hline \multirow{4}{*}{ : } & $\begin{array}{l}\text { Oxygen } \\
\text { production }\end{array}$ & All ecosystems & $\begin{array}{l}\text { Oxygen emission/tonnes of } \\
\text { oxygen/ha/year }\end{array}$ & $\begin{array}{l}\text { Local } \\
\text { Regional } \\
\text { National } \\
\text { Global }\end{array}$ & $\begin{array}{l}\text { Market prices } \\
\text { Cost of alternative }\end{array}$ \\
\hline & $\begin{array}{l}\text { Provision of } \\
\text { habitats }\end{array}$ & All ecosystems & $\begin{array}{l}\text { Shannon's Index of } \\
\text { Biodiversity }\end{array}$ & $\begin{array}{l}\text { Local } \\
\text { Regional } \\
\text { National } \\
\text { Global }\end{array}$ & Contingent valuation \\
\hline & Water cycling & All ecosystems & $\begin{array}{l}\text { Łasica's catchment } \\
\text { balance } / \mathrm{mm} / \text { year }\end{array}$ & $\begin{array}{l}\text { Local } \\
\text { Regional } \\
\text { National } \\
\text { Global }\end{array}$ & Not applicable \\
\hline & Soil formation & All ecosystems & $\begin{array}{l}\text { Amount of topsoil } \\
\text { formed } / \text { ha/year }\end{array}$ & $\begin{array}{l}\text { Local } \\
\text { Regional } \\
\text { National } \\
\text { Global }\end{array}$ & Cost of alternative \\
\hline
\end{tabular}




\begin{tabular}{|c|c|c|c|c|c|}
\hline Cat. & $\begin{array}{l}\text { Ecosystem } \\
\text { service of KNP }\end{array}$ & $\begin{array}{l}\text { Main KNP cosys- } \\
\text { tems providing } \\
\text { the service }\end{array}$ & Proposed indicator/unit & $\begin{array}{l}\text { Scale of } \\
\text { service }\end{array}$ & $\begin{array}{l}\text { Proposed economic } \\
\text { valuation methods }\end{array}$ \\
\hline \multirow{6}{*}{ 蔦 } & $\begin{array}{l}\text { Nature-based } \\
\text { tourism and } \\
\text { recreation }\end{array}$ & All ecosystems & Number of visitors/year/ha & $\begin{array}{l}\text { Local } \\
\text { Regional }\end{array}$ & $\begin{array}{l}\text { Travel cost method } \\
\text { Market prices }\end{array}$ \\
\hline & $\begin{array}{l}\text { Ecological } \\
\text { education }\end{array}$ & All ecosystems & $\begin{array}{l}\text { Number of hours spent on } \\
\text { educational visits/year }\end{array}$ & $\begin{array}{l}\text { Local } \\
\text { Regional }\end{array}$ & $\begin{array}{l}\text { Market prices } \\
\text { (of an hour of } \\
\text { classes) }\end{array}$ \\
\hline & $\begin{array}{l}\text { Scientific } \\
\text { research }\end{array}$ & All ecosystems & Not applicable & $\begin{array}{l}\text { Local } \\
\text { Regional } \\
\text { National }\end{array}$ & Contingent valuation \\
\hline & $\begin{array}{l}\text { Reha- } \\
\text { bilitation and } \\
\text { resocialization }\end{array}$ & $\begin{array}{l}\text { Pine forests Fresh } \\
\text { meadows }\end{array}$ & $\begin{array}{l}\text { Number of hours spent on } \\
\text { therapeutic visits/year }\end{array}$ & Local & $\begin{array}{l}\text { Market prices } \\
\text { (of an hour of } \\
\text { therapeutic visit) } \\
\text { Contingent valuation }\end{array}$ \\
\hline & $\begin{array}{l}\text { Artistic } \\
\text { inspiration }\end{array}$ & All ecosystems & Not applicable & $\begin{array}{l}\text { Local } \\
\text { Regional } \\
\text { National }\end{array}$ & Contingent valuation \\
\hline & $\begin{array}{l}\text { Aesthetic } \\
\text { experience }\end{array}$ & All ecosystems & Not applicable & $\begin{array}{l}\text { Local } \\
\text { Regional } \\
\text { National }\end{array}$ & Hedonic pricing \\
\hline
\end{tabular}

Source: de Groot, 2002, Hawkins, 2003, and Glave, Egan, 2013.

\section{Main regulating ecosystem services of Kampinos National Park for Warsaw and neighboring communities}

\section{Climate regulation}

It is difficult to precisely estimate the extent of KPN influence on Warsaw in terms of climate and air quality regulation without detailed analyses, which are not readily available and complicated to perform. Neighbouring with Warsaw from the West, the park lies on the way of $24,7 \%$ of winds entering the metropolitan area, adjoining the inlets of two of the city's main ventilating corridors (Miejska Pracownia Planowania Przestrzennego i Strategii Rozwoju, 2006 ). The regulatory influence of KNP on the capital's mezoclimate is based mostly on mitigation of urban heat island by supplying air characterized by lower temperature and higher humidity than in the urbanised areas. Particularly the first aspect is valuable from the point of view of the inhabitants of urban areas. This particular ecosystem service can be quantified by comparing average summer temperatures in the KNP, its vicinity and areas located further into the city (Wierzbicki, Andrzejewska., 2007). Then it can be evaluated on the basis of the electricity saving achieved by means of reduced use of air conditioning in summer, using market prices value method. From a wider point of view, the influence of KNP ecosystems on the climate can be estimated on the basis of carbon dioxide sequestration. Even the most basic calculation, based on average carbon stock of particular forms of land cover (IPCC, 2000), shows the importance of climate regulation service supplied by KNP ecosystems: 
Estimated carbon stock of KNP (tonnes):

$\begin{array}{lr}\text { Forests (28259 ha): } & 4748406 \\ \text { Grasslands (5782,2 ha): } & 1542996 \\ \text { Croplands (1922,9 ha): } & 175787 \\ \text { TOTAL: } & 6467189 \text { tonnes }\end{array}$

This final result of this calculation is understated, since it does not include wetlands. Many of KNP ecosystems classified as forests and grasslands are in fact wetland ecosystems. However, such quantification is possible and its result may serve as a basis for economic evaluation, using market prices method, applying the value of the $\mathrm{CO} 2$ emission permit.

\section{Air quality regulation}

Alongside with climate regulation function, air quality regulation is another benefit that Warsaw agglomeration derives from location of KNP on its western outskirts. Comparison of content of major pollutants- sulphur dioxide (SO2), nitrogen oxide (NO2)and suspended dust (PM10)- showed that annual average content of those compounds in KNP is no higher than $9 \%$ of the acceptable norm in case of SO2, 37\% in case of $\mathrm{NO} 2$ and 56\% in case of PM10, meanwhile in case of chosen monitoring stations in Warsaw it reached, respectively, 55\%, 79\% and 76\%. Ecosystem services of KNP related to air purification could be quantified on the basis of average removal rates for $\mathrm{SO} 2$, NO2 and suspended dust by broadleaves and conifers and valuated using market prices or cost of alternative method, based on the cost of industrial removal of those compounds from air.

\section{Water flow regulation and flood prevention}

Water flow regulation is an important ecosystem service of Kampinos National Park, mainly from the point of view of communities located within the catchment of Łasica, main channel draining the area of the park and neighboring communities. Due to geomorphologic conditions groundwater level has always been high in the area, generating issues related to flooding and reduced area available for development and agriculture. This service can be quantified on the basis of catchment water balance of Łasica channel, which encompasses the entire Kampinos National Park (Fig. 1). It has been calculated on the basis of 50 years of monitoring.

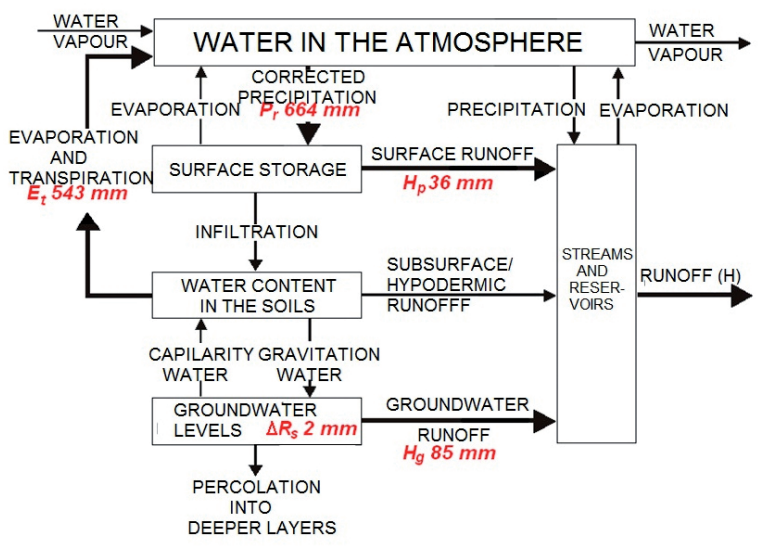

Figure 1. Yearly catchment balance of the Lasica channel

Source: Andrzejewska, 1998. 
The calculations showed that due to high forest cover almost entire precipitation water is being utilized in the process of evapotranspiration. It has fundamental meaning in flood control. Economic valuation of this ecosystem service can be performed using either cost of alternative method- where the alternative could be the cost of building constructions which could prevent flooding with equal efficacy as KNP ecosystems, or avoided damage method, based on the cost of property damaged in flooding.

\section{Erosion prevention}

The issue of erosion in Kampinos National Park is a serious one, since the park is located entirely on fluvial and dune sands prone to eolic erosion (Konecka-Betley, 2003). The sands in wetland areas are covered by layer of organic soils, meanwhile dune complexes are stabilized by pine forests. The importance of KNP ecosystems for mitigation of erosion processes was verified beyond doubt after II World War, when due to extensive deforestation the dunes were destabilized and started moving again, causing severe damage in vegetation cover and property- there are known cases from the period between World War I and World War II, when entire houses located i KNP were covered by sand. In case of Kampinos National Park erosion prevention service could be quantified by calculation of yearly soil loss on areas deprived of vegetation. Evaluation of this ecosystem service can be conducted similarly to the flood prevention service- using either cost of alternative method or avoided damage method.

\section{Main cultural ecosystem services of Kampinos National Park for Warsaw and neighboring communities}

\section{Nature-based tourism and recreation}

This group of KNP ecosystem services has been gaining importance in recent years. Kampinos National Park is the only national park in central Poland and one of the largest forest complexes. Entrance to the park is free of charge. The area is accessible via $350 \mathrm{~km}$ of hiking trails, $200 \mathrm{~km}$ of bike trails and 8 interpretive trails. Visitors have at their disposal 19 parking lots and 12 recreation fields. Study conducted by K. Dzioban (2012) showed that KNP is visited yearly by almost one million people, out of whom $73 \%$ come from Warsaw. Each year around 400 permits are issued for various activities, like bonfires, organized parties and sports events.The majority of tourists (55\%) visit KNP in with a purpose of active recreation in mind, and $59 \%$ as a primary gain of visit indicate physical activity. Since KNP is not an actual touristic destination (hardly anyone stays overnight in the park, which is a requirement to be classified as a tourist), the method of quantification and evaluation of this ecosystem service might not be as straightforward as it usually is. Number of visitors is difficult to assess precisely, since there are no entrance tickets and yearly monitoring of touristic use on an area of such size is problematic to conduct. As for evaluation method, the majority do not actually come to see something new or extraordinary (Dzioban, 2012), therefore travel cost valuation method might not reflect the actual value of KNP ecosystems from the point of view of their recreational users. Since the majority of users engage in some sort of physical activity, it might be convenient to apply cost of alternative method, based on the average cost of attending a gym for the same amount of time which is spent doing sports in the park. In favor of this method is the fact that the data concerning time spent by users in KNP is readily available. 


\section{Ecological education}

Ecological education is one of the major branches of KNP activities. There are three educational facilities under the park's management: Education Center in Izabelin, Education Centre in Granica and European Bison Breeding Centre. Each year they are visited by over 40000 people, including 630 school groups. Calculations of total number of participants of all educational activities in the park showed that each year over 100000 people are included in educational activities of some sort. It should be noted that almost all of these activities are free of charge, except for guided educational trips for adults and classes for school groups from communes located outside of the park. The data concerning amount of time spent by each group on educational activities is readily available, therefore the educational ecosystem services of KNP could be valuated using market price method (based, for example, on the cost of an hour of class or teacher's hourly wages).

\section{Scientific research}

Close proximity of the biggest academic centre in Poland makes Kampinos National Park an attractive destination for researches from major scientific institutions. Large area, specific natural conditions, protected status and rapidly developing buffer zone determine its high value as a testing ground for many disciplines. One of the KNP departments is responsible exclusively for research and monitoring in the park. Large group of most renowned public universities from Warsaw maintains scientific cooperation with employees of Kampinos National Park or leads research and monitoring projects of their own. The issue of quantification and evaluation of ecosystem services related to scientific research is disputable (Glave, Egan, 2013), but one of the most frequently proposed methods is calculation of the number new research activities that take place in a given ecosystem or area in a year. In case of Kampinos National Park it is $60-70$ new research projects per year and 20 ongoing research projects of KNP specialists. Additionally, KNP specialists conduct an ongoing monitoring of climate and abiotic conditions (4 topics), flora (7 topics)and fauna (21 topics). Base Station for Integrated Monitoring of Natural Environment conducts further 14 topics. However, economic valuation of this ecosystem service is controversial (Glave, Egan, 2013). It appears that the most sound from available methods is contingent valuation.

\section{Rehabilitation and resocialization}

This group of cultural ecosystem services does not occur in literature devoted to the subject. It might be due to the fact that it is relatively infrequent that inmates and patients constitute a specific, significant group of ecosystem users. In Kampinos National Park, however, ecosystem services related to therapeutic and rehabilitating activities are not to be overlooked. Several institutions, including hospitals and rehabilitations centres are located within the park. Beneficial influence of unspoiled, natural environment on human wellbeing is indisputable, even when the interaction between nature and the patient is limited to a view through a window (Ulrich, 1984). Quantification and economic valuation of this ecosystem service poses a challenge, since the extent of profit patients derive from recuperating in a natural setting is extremely individualised. However, at least one component of this ecosystem service of KNP could be subjected to quantification and valuation. On the basis of cooperation agreement, patients and inmates from various institutions perform different tasks for KNP as a part of their therapy or resocialisation process. In years 2012 and 201320 prisoners performed several tasks for KNP, including renovation and maintenance of touristic infrastructure, elimination of alien species, elimination of bushes from meadows, mowing of meadows and collecting of litter. In year 201330 patients from Rehabilitation Centre for People Addicted to Psychoactive 
Substances renovated signage of $560 \mathrm{~km}$ of touristic trails in KNP. The most straightforward way of quantification of this ecosystem service would be calculation of hours spent by patients and inmates at work in the park. Economic valuation could be based on market prices of hour of therapy.

\section{Artistic inspiration}

Kampinos National Park is popular among artists engaging in photography, filmmaking, painting and literature activities. Nature- based artistic activities take various forms, from individual endeavours to mass cultural events of a national scale. The extent of these activities can be estimated on the basis of number of permits for artistic endeavours and number and attendance of artistic events taking place in the park. Quantification and evaluation of this group of ecosystem services has been widely discussed (Milcu et al, 2013) as their importance as a component of overall ecosystem value is agreed upon, yet problematic to assess. One of the more frequently suggested methods of economic valuation of this group of services is contingent valuation (Hawkins K, 2003). Another possibility is travel cost method.

\section{Aesthetic experience}

Over $12 \%$ of people visiting Kampinos National Park as a primary gain from visit state aesthetic experience (Dzioban, 2012). Research of landscape perception has repeatedly shown that people perceive as aesthetically pleasing landscapes that are either natural, or transformed in such way that man-made elements harmonize with the surroundings (Daniel, 2001). KNP, aside from protection of natural ecosystems and renaturalisation of transformed ones, also protects semi-natural ecosystems which appeared as a result of agricultural activities in the past. On privately owned areas encompassed in landscape protection in KNP traditional agriculture practices are allowed and traditional housing forms are encouraged. Aesthetic value of KNP ecosystems could be therefore valuated using hedonic pricing method, using data gathered from owners of property located within the park (Constanza et al., 2006). Another possible method is contingent valuation or travel cost method using data gathered from tourist visitors, since the value of tourism ecosystem service is intrinsically related to aesthetic qualities of the place (EFTEC, 2005).

\section{Conclusion}

The example of Kampinos National Park and its buffer zone shows the necessity of adapting a holistic, comprehensive approach to the evaluation of benefits which humans derive from natural environment (Daniel, 2001). Like many other areas of well- preserved nature, KNP attracts growing attention of investors - surrounding settlements experience an influx of new inhabitants, mainly from Warsaw, and the Park is subjected to growing touristic use. It causes increased pressure of urbanisation, which in many cases poses a threat to the ecosystems of the park. The common understanding of an actual value of KNP ecosystems among the general public is superficial, which contributes to antagonistic attitudes towards park regulations resulting from the need to protect them. Although the inhabitants of Warsaw benefit directly from the existence of KNP, by many it is considered merely to be a barrier for investment processes. Therefore, Kampinos National Park, due to its specificity, provides an excellent testing ground for the research and evaluation of ecosystem services. The wider application of this concept could provide the managers of KNP with a powerful tool for spreading knowledge of the actual value of Kampinos National Park ecosystems from the perspective of Warsaw and other 
neighboring communities and, thus, improving their protection. Consequently, the results could aid in verifying the actual efficacy of ecosystem services concept as an awareness- raising method in realities of a large protected area facing significant anthropopressure. However, there is still much room for discussion concerning the choice of ecosystem services that would have priority in evaluation process as well as methods that would be applied in it. Provisioning ecosystem services, which are most straightforward to estimate and evaluate, in case of areas of protected nature play marginal role and their value does not reflect the actual worth of given ecosystem. Cultural services, which undoubtedly play a major role in improving the quality of life of inhabitants of neighboring areas, are frequently difficult or impossible to quantify and translate into economic value. However, regulating ecosystem services of Kampinos National Park are not only extremely important from the point of view of surrounding communities, but also reasonably easy to assess and valuate. It should become one of the priorities of Kampinos National Park management to analyze regulating services of its ecosystems to obtain new method of conveying knowledge about importance of their conservation.

\section{Acknowledgement}

Research partially funded with a grant of the National Centre of Science no DEC-2012/07/B/ /HS4/00306.

\section{References}

Andrzejewska A., 1998. Water balance for the protected catchment of Kampinos National Park. Long term Ecological Research, Examples, Methods, Perspecives for Central Europe. Proceedings of he ILTER Regional Workshop. Mądralin.

Brander L., McEvoy P., 2012. The economic value of ecosystem services from the terrestrial habitats of the Isle of Man. Report for the Department of Environment, Food and Agriculture, Isle of Man Government. Isle of Man.

Costanza et al., (2006), 'The Value of New Jersey's Ecosystem Services and Natural Capital', Gund Institute for Ecological Economics, a good background to valuing nature. At: http://www. nj.gov/dep/dsr/naturalcap/

Daniel, T. C., 2001. Whither scenic beauty? Visual landscape quality assessment in the 21st century. w: Landscape and Urban Planning 54. Elsevier. pp. 267- 281.

DEFRA, 2007. An introductory guide to valuing ecosystem services. Department for Environment, Food and Rural Affairs (DEFRA) London.

de Groot, R. S., M. A. Wilson, et al. (2002). A typology for the classification, description and valuation of ecosystem functions, goods and services. Ecological Economics 41(3): pp. 393-408.

Dzioban K, 2012. 'Studia nad ruchem rekreacyjno- turystycznym w Kampinoskim Parku Narodowym'. PhD thesis manuscript, Akademia Wychowania Fizycznego w Warszawie, Warszawa.

EFTEC, 2005. The Economic, Social and Ecological Value of Ecosystem Services: a Literature Review. Final Report for the Department for Environment, Food and Rural Affairs. EFTEC, London. 
Glave P., Egan D., 2013. What is the Value in Valuing Nature? An Overview of Nature Valuation: Context, Development and Current Approaches. Institute of Ecology and environmental management. Ecosystem Services 1: Practical Methods for Demonstrating the Value of Nature to Decision Makers. Birmingham.

Hawkins, K., 2003. Economic Valuation of Ecosystem Services. University of Minnesota, at: http:// www.frc.state.mn.us/documents/council/landscape/SE\%20Landscape/MFRC_Economic_Valuation_Eco systemServices_SE_2003-10-01_Report.pdf.

Intergovernmental Panel on Climate Change, 2000. Summary for Policymakers: Land Use, Land-Use Change, and Forestry. A Special Report of the Intergovernmental Panel on Climate Change.

Kampinoski Park Narodowy, 2011. Projekt Planu Ochrony Kampinoskiego Parku Narodowego na lata 2012-2013. Unpublished materials of Kampinos National Park, Izabelin.

Konecka-Betley K., 2003. Gleby Puszczy Kampinoskiej. Monografia Kampinoskiego Parku Narodowego, t I. Kampinoski Park Narodowy, Izabelin.

Król B.,, Skolimowska-Król M., 2004. Kampinoski Park Narodowy w koncepcjach planistycznych. Monografia Kampinoskiego Parku Narodowego, t II. Kampinoski Park Narodowy, Izabelin.

Miejska Pracownia Planowania Przestrzennego i Strategii Rozwoju, 2006. Opracowanie ekofizjograficzne do studium uwarunkowań i kierunków zagospodarowania przestrzennego m. st. Warszawy. Urząd Miasta Stołecznego Warszawa, Warszawa.

Milcu A., Ioana J., Hanspach D., Abson and Fischer J., 2013. Cultural ecosystem services: a literature review and prospects for future research. Ecology and Society 18(3), $44 \mathrm{pp} .$.

NRC, 2005. Valuing Ecosystem Services. Toward Better Environmental Decision-Making. National Research Council of the National Academies. The National Academies Press Washington, DC.

Solon J., 2003. Przestrzenne zróżnicowanie roślinności rzeczywistej w Kampinoskim Parku Narodowym $i$ w otulinie. Monografia Kampinoskiego Parku Narodowego, t I. Kampinoski Park Narodowy, Izabelin.

Solon J., 2008. Koncepcja "Ecosystem Services" i jej zastosowanie w badaniach ekologicznokrajobrazowych ["Ecosystem Services" concept and its application in landscape-ecological studies]. Problemy Ekologii Krajobrazu 21: pp. 25-44.

UNEP, 2005. Ecosystems and their services. Ecosystems and Human Well-being. Millenium Ecosystem Assessment. Island Press, Washington, DC.

Ulrich S. R., 1984. View through a window may influence recovery from surgery. Science 224, p. 420(2). American Association for the Advancement of Science. Washington DC.

Wierzbicki, Andrzejewska., 2007. Raport Stacji Bazowej Zintegrowanego Monitoringu Środowiska Przyrodniczego „Pożary” za rok 2006. Kampinoski Park Narodowy, Granica. 
http://rcin.org.pl 